\title{
KETERLIBATAN ORANG TUA, REGULASI DIRI, AGRESIVITAS MEMPENGARUHI PERILAKU TOLERAN ANAK: PATH ANALYSIS
}

\author{
Yubaedi Siron \\ Universitas Islam Negeri Syarif Hidayatullah Jakarta \\ Email: yubaedi.siron@uinjkt.ac.id \\ Rachmat Mulyono \\ Universitas Islam Negeri Syarif Hidayatullah Jakarta \\ Email: rachmat.mulyono@uinjkt.ac.id
}

Article received: 14 Agustus 2018, Review process: 20 Agustus 2018

Article published: 30 Maret 2019

\begin{abstract}
Child-tolerant behavior becomes an important aspect of child development to be developed. The potential for future intolerance can be minimized if tolerant behavior is well stimulated in early age. The objective of this study is to analyze the effect of parental involvement, child self-regulation, and child aggression to the child tolerant behavior. The research used path analysis technique. There are 150 children at 5-6 years-old and 150 their parents in East Jakarta involved in this study taken by simple random sampling. The results of this study revealed: 1) There is no direct effect of parental involvement to the child tolerant behavior; 2) There is a direct effect of child's self-regulation to the child tolerant behavior; 3) There is no direct effect of child aggression to the child tolerant behavior; 4) There is a direct negative effect of parental involvement to the child aggression; 5) There is a direct negative effect of the child's self-regulation to the child aggression; 6) There is a direct effect of parental involvement to the child self-regulation.
\end{abstract}

Keywords: Tolerant Behavior, Parental Involvement, Self Regulation, Aggressiveness.

Abstrak

Perilaku toleran anak merupakan aspek penting dari perkembangan anak yang akan dibentuk. Potensi untuk masa depan intoleransi bisa diminimalisasi jika perilaku toleran yang tidak baik dirangsang pada awal usia anak. Tujuan penelitian ini adalah untuk menganalisis efek keterlibatan orang tua, regulasi diri anak, agresifitas serta perilaku toleran anak. Teknik analisis data dalam penelitian ini yakni 150 anak-anak usia 5-6 tahun dan 150 orang tua yang berada di Jakarta Timur dengan menggunakan teknik acak sederhana. Hasil studi ini menunjukan bahwa: 1) tidak ada efek langsung dari keterlibatan orang tua kepada perilaku 
toleran anak; 2) Terdapat keterkaitan langsung dari regulasi diri anak terhadap perilaku toleran anak; 3) tidak ada efek langsung dari perilaku agresif anak terhadap prilaku toleran anak; 4) Terdapat dampak negatif yang langsung dari keterlibatan orang tua terhadap agresifitas anak; 5) Terdapat dampak negatif yang langsung dari regulasi diri anak terhadap agresifitas anak; 6) Terdapat keterkaitan langsung dari keterlibatan orang tua terhadap regulasi diri anak.

Kata Kunci: Prilaku Toleran, keterlibatan orang tua, Regulasi diri dan agresivitas

\section{PENDAHULUAN}

Intoleransi dan radikalisasi di Indonesia cenderung mengindikasikan toleransi negatif. Munculnya gerakan-gerakan radikalisme, terorisme semakin banyak. Begitu juga gerakan anti-kebhinekaan, bahkan munculnya gerakan anti NKRI dan anti Pancasila untuk menggantikan ideologi negara Indonesia.

Perilaku intoleran tersebut kini tidak hanya merambah pada orang dewasa saja, tetapi sudah masuk ke sekolah-sekolah. Ada beberapa sekolah yang sudah mendeklarasikan dirinya untuk tidak mengajarkan ke peserta didik tentang pendidikan kewarganegaraan, menolak untuk mengibarkan bendera merah putih, karena menganggap Indonesia sebagai negara toghut serta ajaran-ajaran antikebhinnekaan yang diajarkan di sekolah-sekolah.

Survey yang dilakukan Wahid Foundation sebanyak 7,7 persen bersedia melakukan tindakan radikal bila ada kesempatan dan sebanyak 0,4 persen justru pernah melakukan tindakan radikal. Angka 7,7 persen tersebut menjadi proyeksi dari 150 juta umat Islam Indonesia. Artinya jika diproyeksikan, terdapat sekitar 11 juta umat Islam Indonesia yang bersedia bertindak radikal. (Kompas 1/8/2016).

Penelitian yang dilakukan Setara Institute tentang tingkat toleransi siswa yang melibatkan 760 siswa SMA di Jakarta dan Bandung mengungkap 0,3 persen siswa berpotensi menjadi teroris. 35,7 persen siswa memiliki sikap intoleran pasif atau hanya sebatas pikiran, dan 2,4 persen siswa memiliki sikap intoleran aktif atau sampai pada tahap tidak suka. (CNN Indonesia 25/5/2016).

Konflik karena sentimen agama masih terjadi pada kehidupan bermasyarakat. Idealnya, hubungan baik antar sesama harus selalu diciptakan, apalagi Indonesia merupakan negara yang sangat majemuk. Indonesia sebagai negara berpenduduk keempat terbesar di dunia memiliki kemajemukan di berbagai bidang seperti suku, budaya, etnis, sistem sosial 
termasuk agama. Indonesia memiliki lebih dari tujuh belas ribu pulau, tidak kurang ada 1.128 suku dan 750 bahasa daerah dengan jumlah penduduk Indonesia separuh dari jumlah penduduk ASEAN. (Kemdikbud, 2017). Perbedaan dan keragaman agama di Indonesia bisa menjadi potensi munculnya konflik dan disintegrasi bangsa bila tidak dikelola dengan baik, bila masing-masing tidak memahami, curiga, fanatisme berlebihan terhadap agama dan keyakinan. Sebaliknya, bila keragaman dapat dikelola dengan baik dan adil, maka akan melahirkan sikap pengertian bahwa perbedaan merupakan rahmat dan fitrah ilahi yang patut disyukuri dan justru menjadi khazanah bangsa Indonesia.

Masuknya intoleransi ke sekolah-sekolah, sudah sepatutnya untuk dicari alternatif solusi melalui model pendidikan toleransi. Membumikan pendidikan toleransi sejak dini merupakan salah satu langkah strategis untuk menciptakan masyarakat yang toleran. Jika forum pimpinan PTKIN seluruh Indonesia sudah menyepakati "Deklarasi Aceh" pada April 2017 untuk melarang berbagai bentuk kegiatan yang bertentangan dengan Pancasila, dan antiNKRI, intoleran, radikal dalam keberagamaan, serta terorisme di seluruh PTKIN, lembaga pendidikan formal dibawahnya belum mempunyai pijakan dan panduan dalam mengimplementasikan pendidikan toleransi, (Kemenag, 2017). Sehingga penelitian ini sangat penting untuk dilakukan. Penelitian ini bertujuan untuk mencari faktor-faktor yang memengaruhi perilaku toleran pada anak. Faktor-faktor yang akan diteliti yaitu keterlibatan orang tua, regulasi diri, dan agresivitas.

Keterlibatan menjadi penting bagi perkembangan anak untuk dapat berperilaku toleran dan sesuai dengan norma yang berlaku. Orang tua yang terlibat dalam pengasuhan menjadikan anak dapat terstimulasi dengan baik (Henderson dalam Wahyu, 2012). Begitu juga (Hastuti, Fiernanti, and Guhardja 2011) mengungkapkan bahwa orang tua yang agresif akan berpengaruh kepada anak yang agresif juga. Karena anak akan meniru perilaku orang tua.

Begitu juga regulasi diri, yang merupakan kontrol perilaku independen anak untuk menegaskan pemahamannya terhadap harapan sosial. Regulasi diri merupakan kemampuan untuk menghalangi impuls dan mengontrol perilaku seseorang dalam kondisi tidak adanya kontrol eksternal segera telah berulang kali berhubungan dengan ukuran perkembangan kata hati, seperti menolak godaan dan memperbaiki tindakan yang salah. Hal tersebut 
menunjukkan bahwa anak belajar mengendalikan diri melalui pengamatan serta melalui imbalan dan hukuman yang mereka alami. Regulasi diri merupakan dasar anak untuk bersosialisasi (Eisenberg dalam Papalia, 2008). Regulasi diri memiliki peran penting dalam meningkatkan perilaku toleran anak.

Lain halnya dengan agresivitas anak yang tinggi diindikasikan dapat memicu minimnya perilaku toleran anak kepada orang lain di lingkungan sekitarnya. Lebih lanjut, Anderson \& Bushman (2002) menyatakan individu yang sering melakukan kekerasan cenderung akan melakukan tindakan agresif. Tindakan agresif ini akan memicu pada tindakan-tindakan intoleran.

Tinjauan psikologis ini akan bermanfaat untuk kajian dalam mengembangkan model pendidikan toleransi serta dapat dijadikan sebagai acuan dalam pembuatan kebijakan pendidikan toleransi di sekolah.

Secara umum, penelitian ini bertujuan untuk mencari informasi tentang apa saja yang memengaruhi perilaku toleran anak, dengan meninjau keterlibatan orang tua, regulasi diri anak, serta tingkat agresivitas. Secara khusus, penelitian ini bertujuan untuk: 1) Menganalisis pengaruh langsung pengaruh langsung keterlibatan orang tua terhadap perilaku toleran; 2) Menganalisis pengaruh langsung regulasi diri terhadap perilaku toleran, 3) Menganalisis pengaruh langsung agresivitas terhadap perilaku toleran, 4) Menganalisis pengaruh langsung keterlibatan orang tua terhadap regulasi diri, 5) Menganalisis pengaruh langsung keterlibatan orang tua terhadap agresivitas, 6) Menganalisis pengaruh langsung regulasi diri terhadap agresivitas.

\section{METODOLOGI}

Penelitian ini dilakukan di PAUD yang terletak di wilayah Jakarta Timur. Lokasi penelitian dipilih secara purposive dengan pertimbangan bahwa wilayah Jakarta Timur merupakan wilayah administratif terluas dan memiliki paling banyak penduduk di Provinsi DKI Jakarta. Lokasi penelitian dipilih secara purposive yaitu di TK At Tin, PAUD Ria Pembangunan, TK Islam Al-Ummahatussholihat, PAUD Wardah, TK Islam Rambutan, TK Islam Al Abror, Penelitian ini dilaksanakan dari bulan Mei hingga November 2017.

Penelitian ini merupakan penelitian cross sectional study dengan menggunakan pendekatan kuantitatif asosiatif kausal dengan teknik atau model analisis jalur. Adapun 
variabel dalam penelitian ini terdiri atas variabel terikat atau disebut variabel endogen, yaitu perilaku toleran anak. Variabel bebas atau disebut sebagai variabel eksogen dalam penelitian ini, yaitu keterlibatan orang tua, regulasi diri anak, dan agresivitas anak.

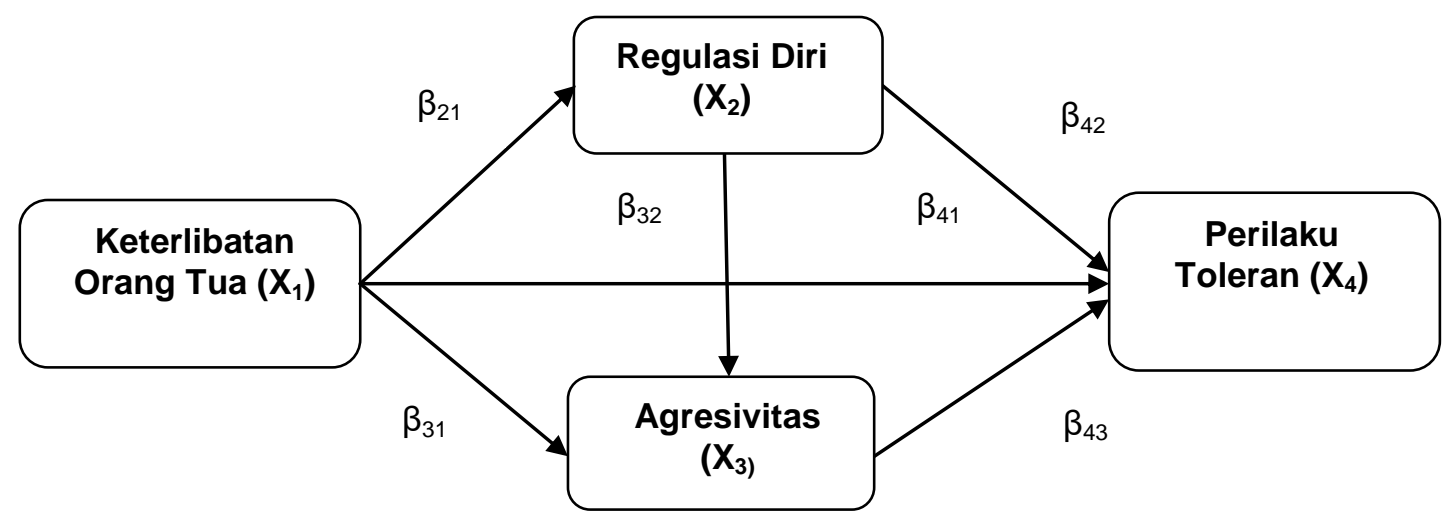

Gambar 1. Model analisis jalur pengaruh keterlibatan orang tua, regulasi diri, dan agresivitas, terhadap perilaku toleran.

Populasi dalam penelitian ini adalah anak yang berusia 5-6 tahun beserta orang tuanya di wilayah Jakarta Timur. Sampel dalam penelitian ini terdiri atas 150 anak beserta 150 orang tuanya yang diambil secara acak sederhana (simple random sampling) yang tersebar di wilayah Jakarta Timur.

Data dalam penelitian ini merupakan data primer yang dikumpulkan dengan menggunakan instrumen yang telah diuji validitas dan reliabilitasnya. Uji validitas dan reliabilitas tersebut dilakukan terhadap keempat variabel yang digunakan dalam peneltian ini. Data perilaku toleran dikumpulkan dengan menggunakan kuesioner yang terdiri atas 31 pertanyaan. Setelah uji validitas, ada 5 pertanyaan yang tidak valid (nomor 3, 9, 10, 24, 26), sehingga tersisa 26 pertanyaan yang digunakan. Komponen-komponen perilaku toleran anak dalam penelitian ini meliputi: 1) tindakan terhadap perbedaan fisik, 2) tindakan terhadap perbedaan ras, 3) tindakan terhadap perbedaan kemampuan, 4) tindakan terhadap perbedaan gender, 5) tindakan terhadap perbedaan budaya, 6) sosialisasi dalam keragaman, 7) menghindari stereotype, 8) menghindari diskriminasi. Penilaian terhadap perilaku toleran anak dilakukan dengan menggunakan skala Likert, yaitu, (1) Tidak Pernah (TP), (2) Jarang (JR), (3) Kadang-Kadang (KD), (4) Sering (SR), dan (5) Selalu (SL). Hasil uji reliabilitas 
menunjukkan bahwa nilai Alpha Cronbach untuk butir-butir instrumen perilaku toleran anak sebesar 0.898. Nilai koefisien alpha tersebut dinyatakan reliable karena nilai $\alpha=0,940>0,6$.

Data keterlibatan orang tua dalam penelitian ini dikumpulkan dengan menggunakan kuesioner yang terdiri atas 29 pernyataan. Setelah dilakukan uji validitas sebanyak 3 pernyataan tidak valid $(25,26,27)$, sehingga instrumen yang dipakai sebanyak 26 pernyataan. Komponen-komponen keterlibatan orang tua dalam penelitian ini meliputi: yang terdiri atas beberapa dimensi, yaitu pengasuhan, keterlibatan orang tua di sekolah, dan keterlibatan orang tua dalam pembelajaran anak di rumah. Penilaian terhadap keterlibatan orang tua dilakukan dengan menggunakan skala Likert, yaitu, (1) Tidak Pernah (TP), (2) Jarang (JR), (3) KadangKadang (KD), (4) Sering (SR), dan (5) Selalu (SL). Hasil uji reliabilitas menunjukkan bahwa nilai Alpha Cronbach untuk butir-butir instrumen perilaku toleran anak sebesar 0.898. Nilai koefisien alpha tersebut dinyatakan reliable karena nilai $\alpha=0,903>0,6$.

Sama halnya dengan perilaku toleran anak dan keterlibatan orang tua, data regulasi diri anak dalam penelitian ini juga dikumpulkan dengan menggunakan kuesioner yang terdiri atas 24 pernyataan. Setelah dilakukan uji validitas, semua pernyataan instrumen regulasi diri anak dinyatakan valid. Komponen-komponen keterlibatan orang tua dalam penelitian ini meliputi: 1) Menahan amarah (sabar), 2) Menahan kegembiraan, 3) Fokus perhatian, 4) Interaksi positif, 5) Melaksanakan tugas pada waktunya tanpa menunggu perintah, 6) Menerima tanggung jawab pribadi, 7) Memiliki inisiatif dalam belajar.

Penilaian terhadap regulasi diri anak dilakukan dengan menggunakan skala Likert, yaitu, (1) Tidak Pernah (TP), (2) Jarang (JR), (3) Kadang-Kadang (KD), (4) Sering (SR), dan (5) Selalu (SL). Hasil uji reliabilitas menunjukkan bahwa nilai Alpha Cronbach untuk butirbutir instrumen perilaku toleran anak sebesar 0.898. Nilai koefisien alpha tersebut dinyatakan reliabel karena nilai $\alpha=0,916>0,6$.

Begitu juga data agresivitas anak dalam penelitian ini juga dikumpulkan dengan menggunakan kuesioner yang terdiri atas 28 pernyataan. Setelah dilakukan uji validitas, ada 2 pernyataan yang tidak valid (nomor 4 dan 7), sehingga instrumen agresivitas anak yang dipakai sebanyak 26 pernyataan. Komponen-komponen keterlibatan orang tua dalam penelitian ini meliputi: 1) Menyakiti orang lain dengan cara menyerang, 2) Menyakiti orang lain dengan cara memukul, 3) Menunjukkan rasa kesal, 4) Tidak mampu mengontrol rasa 
marah, 5) Suka berdebat dengan orang lain, 6) Ketidaksukaan/ketidaksetujuan pada orang lain, 7) Menunjukkan rasa benci, 8) Merasa curiga pada orang lain, 9) Menunjukkan rasa iri hati

Penilaian terhadap agresivitas anak dilakukan dengan menggunakan skala Likert, yaitu, (1) Tidak Pernah (TP), (2) Jarang (JR), (3) Kadang-Kadang (KD), (4) Sering (SR), dan (5) Selalu (SL). Hasil uji reliabilitas menunjukkan bahwa nilai Alpha Cronbach untuk butirbutir instrumen perilaku toleran anak sebesar 0.898. Nilai koefisien alpha tersebut dinyatakan reliabel karena 0,908 > 0,6.

Data dalam penelitian ini akan dianalisis secara statistik, baik dengan menggunakan analisis deskriptif maupun inferensial. Analisis deskriptif dalam penelitian ini dilakukan untuk melihat gambaran sebaran data dari masing-masing variabel. Selanjutnya, data dalam penelitian ini akan diuji dengan menggunakan statistik inferensial namun sebelum melakukan pengujian hipotesis perlu dilakukan pengujian persyaratan analisis, yaitu melakukan uji normalitas data, uji linearitas dan uji signifikansi.

Analisis jalur (path analysis) mempersyaratkan data yang akan dianalisis memenuhi beberapa uji statistik. Beberapa uji statistik yang dilakukan dalam penelitian ini adalah: (1) Uji normalitas galat taksiran regresi; (2) Uji signifikansi dan linearitas model regresi.

\section{HASIL DAN PEMBAHASAN}

Hasil penelitian menunjukkan bahwa skor pencapaian keterlibatan orang tua memiliki rata-rata yang tinggi yaitu sebesar 69,97 persen. Separuh sampel dalam penelitan ini memiliki keterlibatan orang tua yang terkategori sangat tinggi, lebih dari sepertiganya tergolong tinggi dan sisanya tergolong kategori sedang. Adapun sebaran sampel berdasarkan kategori skor keterlibatan orang tua dipaparkan pada Tabel 2.

Tabel 2. Sebaran sampel berdasarkan kategori skor keterlibatan orang tua

\begin{tabular}{|c|c|c|}
\hline \multirow{2}{*}{$\begin{array}{l}\text { Kategori Keterlibatan Orang } \\
\text { Tua }\end{array}$} & \multicolumn{2}{|l|}{ Sampel } \\
\hline & $\mathrm{N}$ & $\%$ \\
\hline Rendah & 0 & 0.0 \\
\hline Sedang & 2 & 1.3 \\
\hline Tinggi & 56 & 37.3 \\
\hline Sangat tinggi & 92 & 61.3 \\
\hline Total & 150 & 100.0 \\
\hline Rata-Rata & 104,96 & $69,97 \%$ \\
\hline
\end{tabular}


Min-Max

$26-130$

Adapun sebaran sampel berdasarkan kategori skor regulasi diri anak dipaparkan pada Tabel 3

Tabel 3 Sebaran sampel berdasarkan kategori skor regulasi diri anak

\begin{tabular}{lll}
\hline \multirow{2}{*}{ Kategori Regulasi Diri Anak } & Sampel \\
\cline { 2 - 3 } & $\mathrm{N}$ & $\%$ \\
\hline Rendah & 0 & 0.0 \\
Sedang & 15 & 10 \\
Tinggi & 77 & 51.3 \\
Sangat tinggi & 58 & 38.7 \\
\hline Total & 150 & 100.0 \\
\hline Rata-Rata & \multicolumn{2}{c}{91,68} \\
\hline Min-Max & $24-120$ & $61,12 \%$ \\
\hline
\end{tabular}

Hasil penelitian menunjukkan bahwa skor pencapaian regulasi diri anak memiliki rata-rata yang tinggi yaitu sebesar $51,3 \%$ persen. Lebih dari sepertinya terkategori sangat tinggi dan sisanya 10\% kategori sedang. Adapun sebaran sampel berdasarkan kategori skor agresivitas anak dipaparkan pada Tabel 4.

Tabel 4. Sebaran sampel berdasarkan kategori skor agresivitas anak

\begin{tabular}{lll}
\hline \multirow{2}{*}{ Kategori Agresivitas Anak } & \multicolumn{2}{l}{ Sampel } \\
\cline { 2 - 3 } & $\mathrm{N}$ & $\%$ \\
\hline Rendah & 64 & 42.7 \\
Sedang & 81 & 54 \\
Tinggi & 5 & 3.3 \\
Sangat tinggi & 0 & 0 \\
\hline Total & 150 & 100.0 \\
\hline Rata-Rata & \multicolumn{2}{c}{54.52} \\
\hline Min-Max & $26-130$ & $34.36 \%$ \\
\hline
\end{tabular}

Hasil penelitian menunjukkan bahwa skor agresivitas anak memiliki rata-rata yang rendah yaitu sebesar 42,7 persen. Begitu juga lebih dari separuh sampel, sebanyak 54\% masuk kategori sedang dan sisanya 3,3\% masuk dalam kategori agresivitas yang tinggi. Adapun sebaran sampel berdasarkan kategori skor perilaku toleran anak dipaparkan pada Tabel 5. 
Tabel 5. Sebaran sampel berdasarkan kategori skor perilaku toleran anak.

\begin{tabular}{lll}
\hline Kategori Perilaku & Toleran & \multicolumn{2}{l}{ Sampel } \\
\cline { 2 - 3 } Anak & $\mathrm{N}$ & $\%$ \\
\hline Rendah & 1 & 0.67 \\
Sedang & 37 & 24.67 \\
Tinggi & 78 & 52 \\
Sangat tinggi & 34 & 22.67 \\
\hline Total & 150 & 100.0 \\
\hline Rata-Rata & \multicolumn{2}{c}{104,96} \\
\hline Min-Max & $26-130$ & $60,24 \%$ \\
\hline
\end{tabular}

Hasil penelitian menunjukkan bahwa skor perilaku toleran anak 22,67\% masuk kategori sangat tinggi, disusul sebanyak 52\% dalam kategori tinggi. Sisanya, sebanyak 24,67 masuk kategori sedang dan $0,67 \%$ masuk kategori rendah.

\section{A. Perhitungan Koefisien Jalur}

Penelitian ini terdiri atas empat variabel, yaitu keterlibatan orang tua $\left(\mathrm{X}_{1}\right)$, regulasi diri anak $\left(\mathrm{X}_{2}\right)$, agresivitas anak $\left(\mathrm{X}_{3}\right)$ dan implementasi pendidikan inklusif $(\mathrm{Y})$. Model struktural yang disajikan dalam penelitian ini terdiri atas tiga substruktur, yaitu substruktur 1 yang terdiri atas variabel $\mathrm{X}_{1}, \mathrm{X}_{2}, \mathrm{X}_{3}$, dan $\mathrm{Y}$; substruktur 2 yang terdiri atas variabel $\mathrm{X}_{1}, \mathrm{X}_{2}$, dan $\mathrm{X}_{3}$; dan substruktur 3 yang terdiri atas variabel $\mathrm{X}_{1}$ dan $\mathrm{X}_{2}$. Adapun konstelasi model struktural penelitian ini divisualisasikan pada Gambar 2.

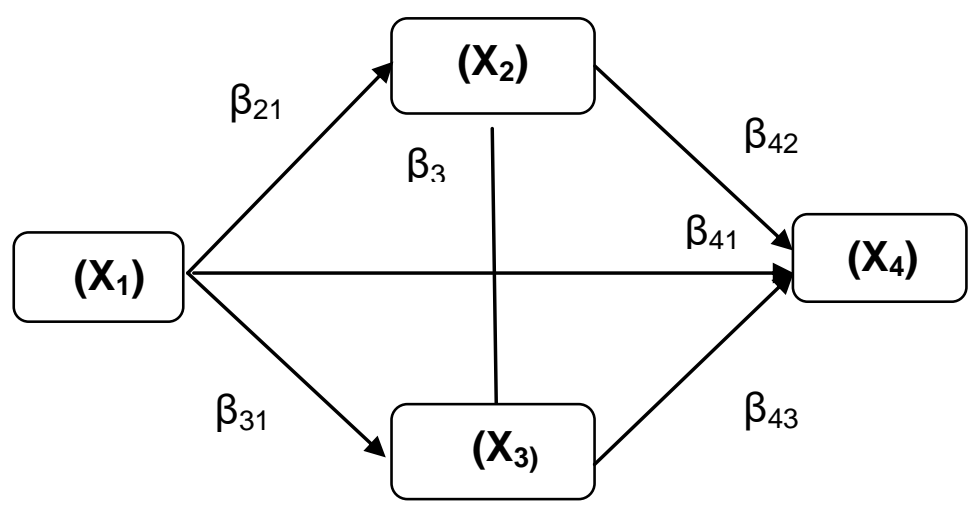

\section{Gambar 2. Konstelasi model struktural}

Keterangan:

$\mathrm{X}_{1}$ : Keterlibatan Orang Tua

$\mathrm{X}_{2}$ : Regulasi Diri Anak 
$\mathrm{X}_{3}$ : Agresivitas Anak

$\mathrm{X}_{4}$ : Perilaku Toleran Anak

\section{Koefisien Jalur pada substruktur 1}

Hubungan kausal antar variabel pada substruktur 1 terdiri dari variabel endogen yaitu variabel $\mathrm{X}_{4}$,dan tiga variabel eksogen yaitu $\mathrm{X}_{1}, \mathrm{X}_{2}, \mathrm{X}_{3}$. Koefisien jalur substruktur 1 dinyatakan dalam persamaan $X_{4}=p_{1} X_{1}+p_{2} X_{2}+p_{3} X_{3}$. Hasil perhitungan koefisien jalur substruktur 1 akan menjadi dasar pengambilan hipotesis pertama, kedua, dan ketiga. Adapun hubungan kausal pada substruktur 1 disajikan pada gambar berikut:

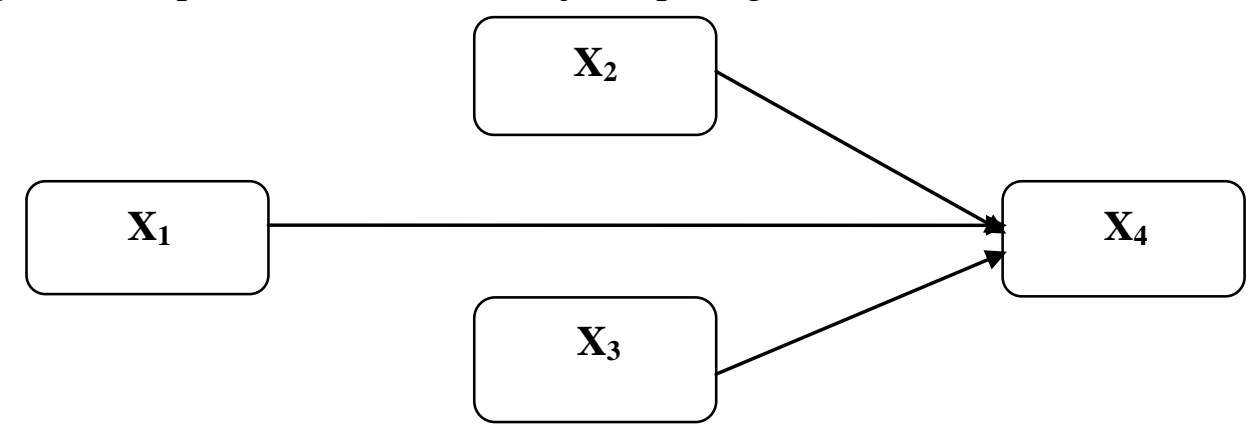

Gambar 3. Model Substruktural 1

Hasil perhitungan menunjukkan nilai koefisien jalur $X_{1}$ terhadap $X_{4}$ sebesar $0.000, X_{2}$ terhadap $\mathrm{X}_{4}$ sebesar 0.379 , dan $\mathrm{X}_{3}$ terhadap $\mathrm{X}_{4}$ sebesar -1.69. Adapun nilai signifikansi masing-masing jalur yaitu, $X_{1}$ terhadap $X_{4}$ sebesar $0.996>0.05$ dengan nilai $t_{\text {hitung }}(0.006)<$ $\mathrm{t}_{\text {tabel }(\alpha=0.05 ; \mathrm{n}=150)}(1.655) ; \mathrm{X}_{2}$ terhadap $\mathrm{X}_{4} 0.000<0.05$ dengan nilai $\mathrm{t}_{\text {hitung }}(3.749)>\mathrm{t}_{\text {tabel }(\alpha=0.05 ;}$ $\mathrm{n}=150)(1.655)$; dan $\mathrm{X}_{3}$ terhadap $\mathrm{X}_{4}$ sebesar $0.107>0.05$ dengan nilai $\mathrm{t}_{\text {hitung }}(-1.621)<\mathrm{t}_{\text {tabel }(\alpha=0.05 \text {; }}$ $\mathrm{n}=150)$ (1.655). Dengan demikian dapat disimpulkan bahwa Keterlibatan Orang Tua dan Agresivitas tidak ada pengaruh langsung terhadap perilaku toleran anak. Akan tetapi, ada pengaruh langsung positif regulasi anak terhadap perilaku toleran anak. 
Tabel 6. Hasil Perhitungan Koefisien Jalur Substruktur 1 model 1

\section{Coefficients $^{\mathrm{a}}$}

\begin{tabular}{|l|l|l|l|l|l|}
\hline \multirow{2}{*}{ Model } & \multicolumn{2}{|l|}{ Unstandardized Coefficients } & Standardized Coefficients & & \\
\cline { 2 - 5 } & $\mathrm{B}$ & Std. Error & Beta & $\mathrm{t}$ & Sig. \\
\hline 1 (Constant) & 57.692 & 23.359 & & 2.470 & .015 \\
KeterlibatanOrtu & .001 & .121 & .000 & .006 & .996 \\
RegulasiDiriAnak & .486 & .130 & .379 & 3.749 & .000 \\
AgresivitasAnak & -.219 & .135 & -.169 & -1.621 & .107 \\
\hline
\end{tabular}

a. Dependent Variable: PerilakuToleranAnak

Hasil analisis menunjukkan bahwa ada koefisien jalur yang tidak signifikan pada model subtruktur 1, maka model pada substruktur ini perlu diperbaiki melalui metode trimming, yaitu metode yang digunakan untuk memperbaiki suatu model struktur analisis jalur dengan cara mengeluarkan variabel eksogen yang koefisien jalurnya tidak signifikan dari model yang telah ditentukan. Cara menggunakan metode trimming adalah dengan menghitung ulang koefisien jalur tanpa menyertakan variabel eksogen yang koefisien jalurnya tidak signifikan. Dengan demikian variabel keterlibatan orng tua dan agresivitas anak akan dikeluarkan dari model dan dilakukan pengujian analisis jalur antara regulasi anak $\left(\mathrm{X}_{2}\right)$ terhadap perilaku toleran anak $\left(\mathrm{X}_{4}\right)$. Adapun hasil perhitungan analisis jalur antara regulasi anak dan perilaku toleran anak dipaparkan pada Tabel 7.

Tabel 7. Hasil perhitungan koefisien jalur $\mathrm{X}_{2}$ terhadap $\mathrm{X}_{4}$ model 2 (sesudah trimming)

\section{Coefficients $^{\mathrm{a}}$}

\begin{tabular}{|l|l|l|l|l|l|}
\hline \multirow{2}{*}{ Model } & \multicolumn{2}{|l|}{ Unstandardized Coefficients } & Standardized Coefficients & & \\
\cline { 2 - 6 } & $\mathrm{B}$ & Std. Error & Beta & $\mathrm{t}$ & Sig. \\
\hline 1 (Constant) & 31.770 & 8.464 & & 3.754 & .000 \\
RegulasiDiriAnak & .639 & .091 & .499 & 6.999 & .000 \\
\hline
\end{tabular}

a. Dependent Variable: PerilakuToleranAnak

Berdasarkan hasil perhitungan koefisien jalur $\mathrm{X}_{2}$ terhadap $\mathrm{X}_{3}$ setelah dilakukan trimming diperoleh nilai koefisien jalur sebesar $\rho \mathrm{x}_{3} \mathrm{x}_{2}=0.499$ dengan nilai signifikansi 
sebesar $0.000<0.05$ dan nilai $t_{\text {hitung }}(6.999)>t_{\text {tabel }(\alpha=0.05 ; n=150)}(1.655)$. Adapun gambaran jalur substruktur 2 yang telah mengalami perubahan divisualisasikan pada Gambar 4

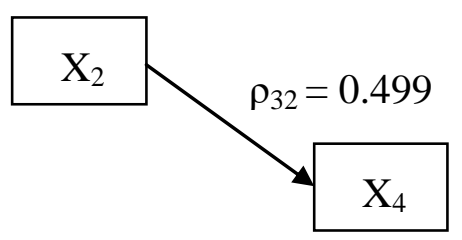

\section{Gambar 4. Model perbaikan substruktur 1}

\section{Koefisien Jalur pada Substruktur 2}

Substruktur 2 terdiri atas variabel endogen yaitu variabel $\mathrm{X}_{3}$ dan dua variabel eksogen yaitu $X_{1}$ dan $X_{2}$. Koefisien jalur substruktur 2 dinyatakan dalam persamaan $X_{3}=\rho_{1} X_{1}+\rho_{2} X_{2}$. Hasil perhitungan koefisien jalur substruktur 2 akan menjadi dasar pengambilan hipotesis keempat dan kelima. Adapun hubungan kausal pada substruktur 2 divisualisasikan pada Gambar 5.

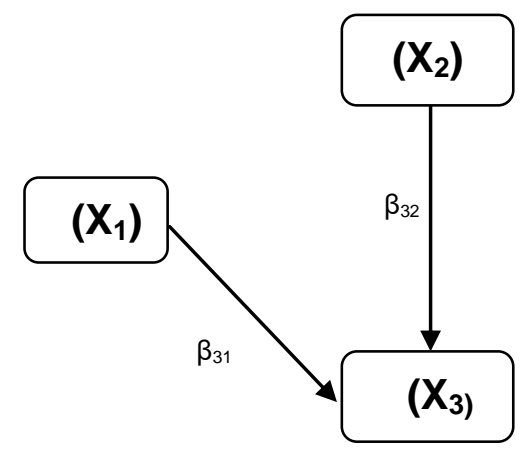

Gambar 5. Model Substruktural 2

Hasil analisis jalur menunjukkan nilai koefisien jalur $\mathrm{X}_{1}$ terhadap $\mathrm{X}_{3}$ sebesar -3.052 dengan nilai signifikansi sebesar $0.003<0.05$ dan nilai $\mathrm{t}_{\text {hitung }}(-3.052)>\mathrm{t}_{\text {tabel }(\alpha=0.05 ; \mathrm{n}=150)}(-$ 1.655). Hal tersebut menunjukkan bahwa ada pengaruh langsung negatif antara variabel keterlibatan orang tua anak terhadap agresivitas anak. Begitu juga nilai yang ditunjukkan oleh jalur $X_{2}$ terhadap $X_{3}$, jalur tersebut menunjukkan nilai koefisien sebesar 0.682 dengan nilai signifikansi sebesar $0.000<0.05$ dan nilai $t_{\text {hitung }}(-11.959)>t_{\text {tabel }(\alpha=0.05 ; n=150)}(-1.655)$. Artinya ada pengaruh langsung negatif antara regulasi diri anak dengan agrsivitas anak. Adapun hasil perhitungan koefisien jalur substruktur 2 dipaparkan pada Tabel 8. 
Tabel 8. Hasil Perhitungan Koefisien Jalur Substruktur 2

\section{Coefficients $^{\mathrm{a}}$}

\begin{tabular}{|l|l|l|l|l|l|}
\hline \multirow{2}{*}{ Model } & \multicolumn{2}{|l|}{ Unstandardized Coefficients } & Standardized Coefficients & & \\
\cline { 2 - 5 } & $\mathrm{B}$ & Std. Error & Beta & $\mathrm{t}$ & Sig. \\
\hline 1 (Constant) & 139.305 & 8.472 & & 16.443 & .000 \\
KeterlibatanOrtu & -.219 & .072 & -.174 & -3.052 & .003 \\
RegulasiDiriAnak & -.674 & .056 & -.682 & -11.959 & .000 \\
\hline
\end{tabular}

a. Dependent Variable: AgresivitasAnak

\section{Koefisien Jalur pada Substruktur 3}

Model substruktur 3 terdiri atas variabel endogen yaitu variabel $\mathrm{X}_{2}$, dan variabel eksogen yaitu $X_{1}$. Koefisien jalur substruktur 3 dinyatakan dalam persamaan $X_{2}=p_{1} X_{1}$. Hasil perhitungan koefisien jalur substruktur 3 akan menjadi dasar pengambilan hipotesis keenam. Adapun hubungan kausal pada substruktur 3 disajikan pada gambar berikut ini:

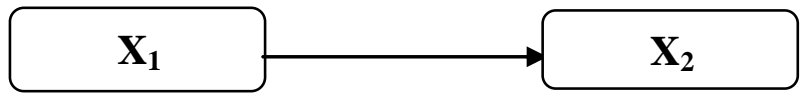

\section{Gambar 8. Model Struktural 3}

Hasil perhitungan analisis koefisien jalur $X_{1}$ terhadap $X_{2}$ diperoleh nilai koefisien jalur sebesar $\rho \mathrm{x}_{2} \mathrm{x}_{1}=0.158$ dengan nilai signifikansi $0.05 \leq 0.05$ dan dengan nilai $t_{\text {hitung }}(1.942)$ $>\mathrm{t}_{\text {tabel }(\alpha=0.05 ; \mathrm{n}=150)}(1.655)$. Adapun hasil perhitungan analisis jalur variabel keterlibatan orang tua terhadap regulasi diri anak dipaparkan pada Tabel 9.

\section{Tabel 9. Hasil Perhitungan Koefisien Jalur Substruktur 3}

\section{Coefficients $^{\mathbf{a}}$}

\begin{tabular}{|l|l|l|l|l|l|}
\hline \multirow{2}{*}{ Model } & \multicolumn{2}{|l|}{ Unstandardized Coefficients } & Standardized Coefficients & & \\
\cline { 2 - 6 } & $\mathrm{B}$ & Std. Error & Beta & $\mathrm{t}$ & Sig. \\
\hline 1 (Constant) & 70.605 & 10.910 & & 6.472 & .000 \\
KeterlibatanOrtu & .201 & .103 & .158 & 1.942 & .054 \\
\hline
\end{tabular}

a. Dependent Variable: RegulasiDiriAnak 


\section{B. Pengujian Hipotesis}

Hasil perhitungan koefisien jalur yang telah diuraikan sebelumnya digunakan untuk menguji hipotesis penelitian, yaitu untuk membuktikan ada atau tidaknya pengaruh langsung variabel eksogen terhadap variabel endogen dalam model struktural. Adapun kriteria uji hipotesis dilakukan dengan mengkonsultasikan nilai $t_{\text {hitung }}$ pada masing-masing jalur dengan nilai $t_{\text {tabel}}$, yaitu tolak $\mathrm{H}_{0}$ jika nilai $\mathrm{t}_{\text {hitung }}$ lebih besar dari nilai $\mathrm{t}_{\text {tabel }}$ pada taraf signifikansi 0.05 dan begitu sebaliknya, terima $\mathrm{H}_{0}$ jika nilai $\mathrm{t}_{\text {hitung }}$ lebih kecil dari nilai $\mathrm{t}_{\text {tabel }}$ pada taraf signifikansi 0.05. Pengujian tersebut dilakukan terhadap semua hipotesis dalam penelitian ini. Adapun pengujian hipotesis-hipotesis tersebut akan dipaparkan sebagai berikut:

\section{Keterlibatan Orang Tua $\left(X_{1}\right)$ tidak berpengaruh langsung terhadap Perilaku Toleran Anak $\left(\mathbf{X}_{4}\right)$}

Hasil perhitungan menunjukkan nilai koefisien jalur $X_{1}$ terhadap $X_{4}$ sebesar 0.000 dengan nilai signifikansi $0.996>0.05$. Selain itu, didapatkan juga nilai thitung sebesar 0.006 . Nilai $t_{\text {hitung }}$ tersebut lebih kecil dibandingkan dengan nilai $t_{\text {tabel }(\alpha=0.05 ; n=150)}$ yaitu sebesar 1.645. Dengan demikian $\mathrm{H}_{0}$ diterima dan $\mathrm{H}_{1}$ ditolak, artinya keterlibatan orang tua tidak memiliki pengaruh langsung terhadap perilaku toleran anak.

2. Regulasi Diri Anak $\left(X_{2}\right)$ berpengaruh langsung positif terhadap Perilaku Toleran Anak $\left(\mathbf{X}_{4}\right)$

Berdasarkan hasil perhitungan, didapatkan nilai koefisien jalur $\mathrm{X}_{2}$ terhadap $\mathrm{X}_{4}$ sebesar 0.499 dengan nilai signifikansi $0.000<0.05$. Selain itu, didapatkan juga nilai $t_{\text {hitung }}$ sebesar 6.999. Dengan demikian Nilai $t_{\text {hitung }}>$ nilai $t_{\text {tabel }(\alpha=0.05 ; n=150)}$ yaitu sebesar 1.645 , maka $H_{0}$ ditolak dan $\mathrm{H}_{1}$ diterima. Berdasarkan hasil tersebut dapat diartikan bahwa regulasi diri anak memiliki pengaruh langsung positif terhadap perilaku toleran anak.

\section{Agresivitas Anak $\left(X_{3}\right)$ tidak berpengaruh langsung terhadap Perilaku Toleran Anak $\left(\mathbf{X}_{4}\right)$}

Hasil analisis jalur menunjukkan nilai koefisien jalur $\mathrm{X}_{3}$ terhadap $\mathrm{X}_{4}$ sebesar -0.169 dengan nilai siginifikansi $0.107<0.05$. Selain itu, didapatkan hasil $t_{\text {hitung }}$ sebesar -1.621 . Nilai $t_{\text {hitung }}$ tersebut lebih kecil dibandingkan dengan nilai $t_{\text {tabel }}(\alpha=0.05 ; n=150)(1.645)$ sehingga $\mathrm{H}_{0}$ diterima dan $\mathrm{H}_{1}$ ditolak maka koefisien jalur tidak signifikan. Dengan demikian dapat 
disimpulkan bahwa agresivitas anak tidak berpengaruh secara signifikan terhadap perilaku toleran anak.

\section{Keterlibatan Orang Tua $\left(X_{1}\right)$ berpengaruh langsung positif terhadap Agresivitas} Anak $\left(\mathbf{X}_{3}\right)$

Hasil perhitungan koefisien jalur $\mathrm{X}_{1}$ terhadap $\mathrm{X}_{3}$ didapatkan nilai koefisien sebesar 0.174 dengan nilai signifikansi $0.003>0.05$. Selain itu, didapatkan juga nilai $t_{\text {hitung }}$ sebesar 3.052. Dengan demikian Nilai $t_{\text {hitung }}<$ nilai $t_{\text {tabel }}(\alpha=0.05 ; n=150)$ yaitu sebesar 1.645 , maka $\mathrm{H}_{0}$ ditolak dan $\mathrm{H}_{1}$ diterima. Berdasarkan hasil tersebut dapat diartikan bahwa keterlibatan orang tua memiliki pengaruh langsung positif terhadap agresivitas anak.

\section{Regulasi Diri Anak $\left(X_{2}\right)$ berpengaruh langsung terhadap Agresivitas Anak $\left(X_{3}\right)$}

Hasil perhitungan koefisien jalur $\mathrm{X}_{2}$ terhadap $\mathrm{X}_{3}$ didapatkan nilai koefisien sebesar 0,682 dengan nilai signifikansi $0.000<0.05$. Selain itu, didapatkan juga nilai $t_{\text {hitung }}$ sebesar 11.959. Dengan demikian Nilai $t_{\text {hitung }}<$ nilai $t_{\text {tabel }(\alpha=0.05 ; n=150)}$ yaitu sebesar 2.000 , maka $\mathrm{H}_{0}$ ditolak dan $\mathrm{H}_{1}$ diterima. Berdasarkan hasil tersebut dapat diartikan bahwa regulasi diri anak memiliki pengaruh positif langsung terhadap agresivitas anak.

\section{Keterlibatan Orang Tua $\left(\mathbf{X}_{1}\right)$ berpengaruh langsung terhadap Regulasi Diri Anak $\left(\mathbf{X}_{2}\right)$}

Hasil penelitian menunjukkan koefisien jalur $X_{1}$ terhadap $X_{2}$ sebesar 0.158 dan nilai $t_{\text {hitung }}$ sebesar 1.942. Jika dibandingkan dengan nilai $t_{\text {tabel }(\alpha=0.05 ; n=150)}(1.645)$, nilai tersebut lebih besar sehingga koefisien jalur tersebut signifikan. Signifikannya koefisien jalur tersebut juga ditunjukkan oleh nilai signifikansi sebesar 0.05 yang sama jika dibandingkan nilai probabilitas 0.05 sehingga dapat dibuktikan bahwa $\mathrm{H}_{0}$ ditolak dan $\mathrm{H}_{1}$ diterima, artinya keterlibatan orang tua memiliki pengaruh positif terhadap regulasi diri anak. Adapun rangkuman hasil pengujian hipotesis dalam penelitian ini dipaparkan pada Tabel 4.5. 
Tabel 4.5 Rangkuman Hasil Pengujian Hipotesis

\begin{tabular}{|c|c|c|c|c|c|c|}
\hline No & Hipotesis & $\begin{array}{l}\text { Koefisien } \\
\text { Jalur }\end{array}$ & $\begin{array}{l}\mathbf{t} \\
\text { hitung }\end{array}$ & $\begin{array}{l}\text { t tabel } \\
\alpha=0.05\end{array}$ & $\begin{array}{l}\text { Keputusan } \\
\mathbf{H}_{0}\end{array}$ & Simpulan \\
\hline 1 & $\begin{array}{lr}X_{1} & \text { berpengaruh } \\
\text { langsung } & \text { positif } \\
\text { terhadap } X_{4} & \end{array}$ & 0.000 & 0.06 & 1.645 & Diterima & $\begin{array}{l}\text { Tidak terdapat } \\
\text { pengaruh } \\
\text { langsung }\end{array}$ \\
\hline 2 & $\begin{array}{lr}\mathrm{X}_{2} & \text { berpengaruh } \\
\text { langsung } & \text { positif } \\
\text { terhadap } \mathrm{X}_{4} & \end{array}$ & 0.499 & 6.999 & 1.645 & Ditolak & $\begin{array}{l}\text { Terdapat } \\
\text { pengaruh } \\
\text { langsung positif }\end{array}$ \\
\hline 3 & $\begin{array}{lr}X_{3} & \text { berpengaruh } \\
\text { langsung } & \text { negatif } \\
\text { terhadap } X_{4} & \end{array}$ & -0.169 & -1.621 & 1.645 & Dite & $\begin{array}{l}\text { Tidak terdapat } \\
\text { pengaruh } \\
\text { langsung }\end{array}$ \\
\hline 4 & $\begin{array}{lr}X_{1} & \text { berpengaruh } \\
\text { langsung } & \text { negatif } \\
\text { terhadap } X_{3} & \end{array}$ & -0.174 & -3.052 & 1.645 & Dit & $\begin{array}{l}\text { Terdapat } \\
\text { pengaruh } \\
\text { langsung negatif }\end{array}$ \\
\hline 5 & $\begin{array}{lr}X_{2} & \text { berpengaruh } \\
\text { langsung } & \text { negatif } \\
\text { terhadap } X_{3} & \end{array}$ & -0.682 & $\begin{array}{l}- \\
11.959\end{array}$ & 1.645 & Ditolak & $\begin{array}{l}\text { Terdapat } \\
\text { pengaruh } \\
\text { langsung negatif }\end{array}$ \\
\hline 6 & $\begin{array}{lr}X_{1} & \text { berpengaruh } \\
\text { langsung } & \text { positif } \\
\text { terhadap } X_{2} & \\
\end{array}$ & 0.158 & 1.942 & 1.645 & Ditolak & $\begin{array}{l}\text { Terdapat } \\
\text { pengaruh } \\
\text { langsung positif }\end{array}$ \\
\hline
\end{tabular}

Dengan demikian model struktur akhir pengaruh variabel eksogen terhadap variabel endogen seperti yang disajikan pada gambar di bawah ini. Adapun konstelasi model struktural penelitian ini divisualisasikan pada Gambar 4.

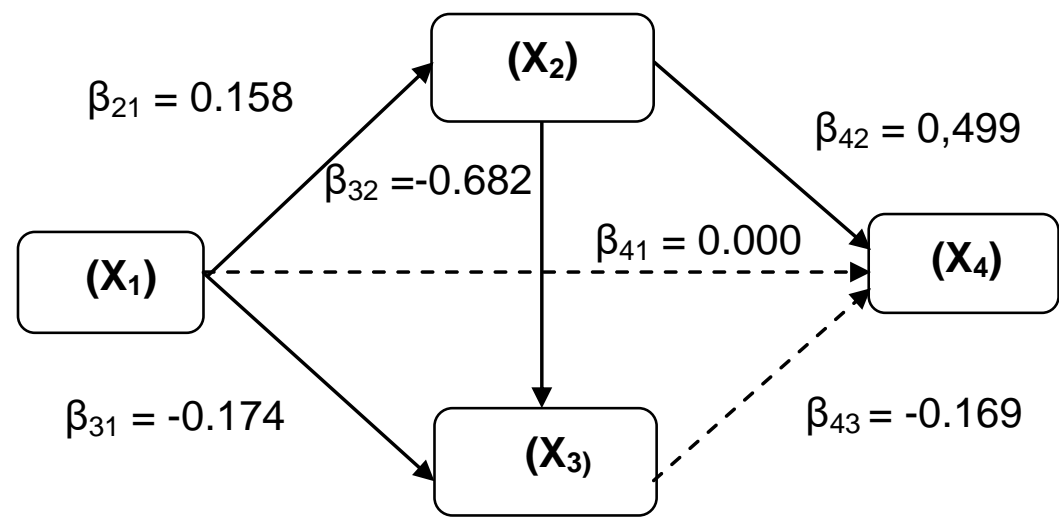

Gambar 9. Model Struktural Akhir Pengaruh Variabel Eksogen terhadap Variabel Endogen 


\section{B. Pembahasan Hasil Penelitian}

\section{Keterlibatan Orang Tua $\left(X_{1}\right)$ tidak berpengaruh langsung terhadap Perilaku Toleran Anak $\left(\mathbf{X}_{4}\right)$}

Penelitian ditemukan bahwa tidak terdapat hubungan yang signifikan antara keterlibatan orang tua $\left(\mathrm{X}_{1}\right)$ dengan perilaku toleran anak $\left(\mathrm{X}_{4}\right)$ yakni tidak terdapat pengaruh langsung positif keterlibatan orang tua $\left(\mathrm{X}_{1}\right)$ terhadap perilaku toleran anak $\left(\mathrm{X}_{4}\right)$. Dengan demikian, dalam konteks penelitian ini, peningkatan keterlibatan orang tua tidak akan berdampak pada peningkatan perilaku toleran anak Walaupun keterlibatan orang tua masuk kategori sangat tinggi, dengan rata-rata 69,97\%, bukan berarti mempunyai pengaruh langsung ke perilaku toleran anak. Hal ini diduga karena relasi keterlibatan orang tua dengan perilaku toleran anak dalam konteks penelitian ini berbeda dengan kerangka teoretik yang telah dibangun. Sebagai contoh, keterlibatan orang tua dalam mendampingi anak belajar, yang merupakan salah satu butir instrumen dalam penelitian ini, tidak serta merta ketika orang tua mendampingi anak belajar, maka anak akan secara langsung mempunyai perilaku toleran yang tinggi, karena keterlibatan yang dibangun dalam peneiltian ini meliputi keterlibatan orang tua di rumah, di sekolah, dan dalam pengasuhan sehari-hari.

\section{Regulasi Diri Anak $\left(\mathbf{X}_{2}\right)$ berpengaruh langsung positif terhadap Perilaku Toleran} Anak $\left(\mathbf{X}_{4}\right)$

Penelitian ditemukan bahwa terdapat hubungan yang signifikan antara regulasi diri anak $\left(X_{2}\right)$ dengan perilaku toleran anak $\left(X_{4}\right)$. Signifikansi hubungan antara $X_{2}$ dan $X_{4}$ dipertegas dengan hasil pengujian hipotesis yang diajukan dalam penelitian ini yakni terdapat pengaruh langsung positif regulasi diri anak $\left(\mathrm{X}_{2}\right)$ terhadap perilaku toleran anak $\left(\mathrm{X}_{4}\right)$. Dengan demikian peningkatan regulasi diri anak akan berdampak pada peningkatan perilaku toleran anak.

Regulasi diri merupakan kontrol perilaku independen anak untuk menegaskan pemahamannya terhadap harapan sosial. Pengendalian diri (self regulation) merupakan kemampuan untuk menghalangi impuls dan mengontrol perilaku seseorang dalam kondisi tidak adanya kontrol eksternal segera telah berulang kali berhubungan dengan ukuran perkembangan kata hati, seperti menolak godaan dan memperbaiki tindakan yang salah (Eisenberg dalam Papalia, 2008) 
Kontrol diri adalah kapasitas untuk mengubah tanggapan diri sendiri, terutama untuk membawa mereka ke arah dengan standar seperti ideal, nilai, moral, dan harapan sosial dan untuk mendukung mengejar tujuan jangka panjang (Baumeister, Vohn dan Tice, 2007). Hasil penelitian ini membuktikan pengaruh positif langsung regulasi diri anak terhadap perilaku toleran anak. Regulasi diri anak merupakan salah satu faktor yang berperan penting agar agar dapat bepeilaku toleran di lingkungannya.

3. Agresivitas Anak $\left(\mathrm{X}_{3}\right)$ tidak berpengaruh langsung terhadap Perilaku Toleran Anak $\left(\mathbf{X}_{4}\right)$

Penelitian ditemukan bahwa tidak terdapat hubungan yang signifikan antara agresivitas anak $\left(\mathrm{X}_{1}\right)$ dengan perilaku toleran anak $\left(\mathrm{X}_{4}\right)$. Ketidakadaan hubungan antara $\mathrm{X}_{1}$ dan $\mathrm{X}_{4}$ dipertegas dengan hasil pengujian hipotesis yang diajukan dalam penelitian ini yakni tidak terdapat pengaruh langsung negatif agresivitas anak $\left(\mathrm{X}_{1}\right)$ terhadap perilaku toleran anak $\left(\mathrm{X}_{4}\right)$. Dengan demikian, dalam konteks penelitian ini, menurunkan agresivitas anak tidak akan berdampak pada peningkatan perilaku toleran anak. Hal ini disebabkan karena perbedaan konteks pada populasi penelitian yang dilakukan. Walaupun agresivitas anak masuk kategori rendah, dengan rata-rata $34,36 \%$, bukan berarti mempunyai pengaruh langsung negatif ke perilaku toleran anak. Hal ini diduga karena relasi variabel agresivitas anak dengan variabel perilaku toleran anak dalam konteks penelitian ini berbeda dengan kerangka teoretik yang telah dibangun. Sebagai contoh, dimensi agresi tidak langsung yang terdiri dari indikator peneltian diantaranya, indikator anak dalam menunjukan rasa benci, merasa curiga pada orang lain dan menunjukkan iri hati, tidak berkontribusi secara langsung ke variabel perilaku toleran yang dikembangkan dalam penelitian ini.

4. Keterlibatan Orang Tua $\left(X_{1}\right)$ berpengaruh langsung positif terhadap Agresivitas Anak $\left(\mathbf{X}_{3}\right)$

Penelitian ditemukan bahwa terdapat hubungan yang signifikan antara keterlibatan orang tua $\left(X_{1}\right)$ dengan agresivitas anak $\left(X_{3}\right)$. Signifikansi hubungan antara $X_{1}$ dan $X_{3}$ dipertegas dengan hasil pengujian hipotesis yang diajukan dalam penelitian ini yakni terdapat pengaruh langsung negatif keterlibatan orang tua $\left(X_{1}\right)$ terhadap agresivitas anak $\left(X_{3}\right)$. Dengan demikian peningkatan keterlibatan orang tua akan berdampak pada menurunnya agresivitas anak. 
Orang tua yang melibatkan diri dalam pengasuhan anak yang baik akan menurunkan tingkat agresivitas anak. Sebagai contoh, indikator pengasuhan yaitu orang tua yang menghindari kekerasan (fisik/verbal) ketika anak melakukan kesalahan. Perilaku tersebut juga akan diteladani oleh anaknya karena anak pada usia ini merupakan fase imitasi, meniru segala perilaku orang sekitar, yang baik maupun buruk.

Orang tua yang memberikan kehangatan dalam berinteraksi juga menjadi faktor penyumbang agresivitas anak menurun. Begitu juga orang tua yang melibatkan kegiatan bermain anak. Anak akan merasa dilibatkan pada aktivitas orang dewasa, sehingga hal ini dapat mengurangi tingkat agresivitas anak.

Orang tua yang menyediakan lingkungan fisik bermain yang nyaman juga memberi sumbangsih pada menurunkan agresivitas anak. Lingkungan yang aman menjadikan anak akan berperilaku sesuai dengan lingkungannya yang aman.

\section{Regulasi Diri Anak $\left(X_{2}\right)$ berpengaruh langsung terhadap Agresivitas Anak $\left(X_{3}\right)$}

Penelitian ditemukan bahwa terdapat hubungan yang signifikan antara regulasi diri anak $\left(\mathrm{X}_{2}\right)$ dengan agresivitas anak $\left(\mathrm{X}_{3}\right)$. Signifikansi hubungan antara $\mathrm{X}_{2}$ dan $\mathrm{X}_{3}$ dipertegas dengan hasil pengujian hipotesis yang diajukan dalam penelitian ini yakni terdapat pengaruh langsung negatif regulasi diri anak $\left(\mathrm{X}_{2}\right)$ terhadap agresivitas anak $\left(\mathrm{X}_{3}\right)$. Dengan demikian peningkatan regulasi diri anak akan berdampak pada menurunnya agresivitas anak.

Regulasi diri anak berperan penting karena didalamnya ada dimensi mengelola emosi, yang terdiri dari menahan amarah (sabar). Anak yang sabar, secara langsung agresivitasnya menurun. Begitu juga anak yang dapat menahan kegembiraannya, dia dapat mengelola agresivitasnya pula.

Anak yang dapat mengatur perilakunya, seperti mengatur fokus perhatian, interaksi positif, serta dapat melaksanakan tugas pada waktunya tanpa menunggu perintah juga dapat berkontribusi mengelola agresivitasnya. Begitu juga anak yang dapat menerima tanggung jawab pribadi dan memiliki inisiatif untuk tindak bertindak agresif. 
6. Keterlibatan Orang Tua $\left(X_{1}\right)$ berpengaruh langsung terhadap Regulasi Diri Anak $\left(\mathbf{X}_{2}\right)$

Penelitian ditemukan bahwa terdapat hubungan yang signifikan antara keterlibatan orang tua $\left(X_{1}\right)$ dengan regulasi diri anak $\left(X_{2}\right)$. Signifikansi hubungan antara $X_{1}$ dan $X_{2}$ dipertegas dengan hasil pengujian hipotesis yang diajukan dalam penelitian ini yakni terdapat pengaruh langsung keterlibatan orang tua $\left(X_{1}\right)$ terhadap regulsi diri anak $\left(X_{2}\right)$. Dengan demikian peningkatan keterlibatan orang tua akan berdampak pada meningkatnya regulasi diri anak.

Orang tua yang terlibat dalam pengasuhan anak, maka akan berpengaruh langsung terhadap regulasi diri anak. Proses reinforcement, punishment, dan imitasi dianggap dapat menjelaskan cara individu belajar tentang respons tertentu dan kenapa respons individu berbeda dengan respons individu lain. Ketika anak diberi reinforcement untuk perilaku yang konsisten sesuai dengan lingkungan sosialnya, maka mereka akan lebih mungkin untuk mengulangi perilaku tersebut (Santrock, 2007). Sebagai contoh, indikator pengasuhan yaitu orang tua yang menghindari kekerasan (fisik/verbal) ketika anak melakukan kesalahan. Perilaku tersebut juga akan diteladani oleh anaknya karena anak pada usia ini merupakan fase imitasi, meniru segala perilaku orang sekitar, baik maupun buruk.

\section{SIMPULAN}

Berdasarkan hasil analisis data, secara rinci beberapa simpulan yang dapat ditarik dari penelitian ini yaitu sebagai berikut:

1. Tidak terdapat pengaruh langsung antara keterlibatan orang tua terhadap perilaku toleran anak. Artinya keterlibatan orang tua tidak serta merta dapat meningkatkan perilaku toleran anak.

2. Terdapat pengaruh langsung antara regulasi diri anak terhadap perilaku toleran anak. Artinya meningkatnya regulasi diri anak akan berdampak langsung terhadap peningkatan perilaku toleran anak.

3. Tidak terdapat pengaruh langsung negatif antara agresivitas anak terhadap perilaku toleran anak. Artinya menurunnya agresivitas tidak serta merta dapat langsung meningkatkan perilaku toleran anak. 
4. Terdapat pengaruh langsung negatif antara keterlibatan orang tua terhadap agresivitas anak. Artinya meningkatnya keterlibatan orang tua akan berdampak langsung terhadap menurunnya agresivitas anak.

5. Terdapat pengaruh langsung negatif regulasi diri anak terhadap pemahaman guru. Artinya meningkatnya regulasi diri anak secara langsung dapat menurunkan agresivitas anak.

6. Terdapat pengaruh langsung antara keterlibatan orang tua terhadap regulasi diri anak. Artinya meningkatnya keterlibatan orang tua akan berdampak langsung terhadap meningkatnya regulasi diri anak.

Berdasarkan temuan empirik penelitian ini menunjukkan bahwa perilaku toleran tidak dipengaruhi oleh keterlibatan orang tua dan agresivitas anak. Perilaku toleran secara langsung dipengaruhi oleh regulasi diri anak. Hal ini tidak sesuai dengan kerangka teoretik yang telah dikembangkan. Hal ini menandakan, hal perlu dilakukan untuk meningkatkan perilaku toleran yaitu meningkatkan regulasi diri anak.

Keterlibatan orang tua dan agresivitas diri anak tidak perlu dipertimbangkan terlalu serius mengingat tidak signifikannya pengaruh kedua variabel dalam penelitian ini. Akan tetapi, keterlibatan orang tua sangat penting ditingkatkan karena dapat menurunkan agresivitas anak, serta dapat meningkatkan regulasi diri anak.

Begitu juga regulasi diri anak menjadi penting ditingkatkan, selain dapat meningkatkan secara langsung perilaku toleran, regulasi diri anak dapat menurunkan agresivitas anak. Singkatnya, untuk menurunkan agresivitas anak, kita perlu meningkatkan keterlibatan orang tua dan regulasi diri anak.

Berdasarkan pada temuan dalam penelitian ini, diharapkan fasilitasi agar keterlibatan orang tua dalam pendidikan dan pengasuhan anak usia dini perlu ditingkatkan. Secara empiris keterlibatan orang tua dapat berpengaruh langsung terhadap menurunnya agresivitas anak. Lebih dari itu, keterlibatan orang tua juga dapat meningkatkan regulasi diri anak. Perlu diketahui, regulasi diri anak berpengaruh secara langsung terhadap perilaku toleran anak. Selain itu, regulasi diri anak juga dapat menurunkan agresivitas anak. Berdasarkan hasil empiris tersebut, meningkatkan keterlibatan orang tua artinya secara tidak langsung meningkatkna perilaku toleran anak. 
Meningkatkan keterlibatan orang tua terdiri dari beberapa aspek, diantaranya dengan: 1) Melibatkan orang tua dalam pengasuhan anak. Literasi orang tua terhadap pengasuhan anak perlu ditingkatkan agar pengasuhan terhadap anak menjadi semakin berkualitas. 2) Melibatkan orang tua di sekolah. Melibatkan orang tua di sekolah dapat dilakukan dengan cara melakukan komunikasi rutin antara orang tua-guru-sekolah, melibatkan orangtua dalam kegiatan sekolah, serta melibatkan orang tua dalam kegiatan perkumpulan orang tua murid dan guru, 3) Melibatkan orang tua dalam pembelajaran anak di rumah. Cara ini dapat dilakukan dengan memberikan pengetahuan kepada orang tua untuk menyediakan lingkungan fisik bermain yang aman untuk anaknya, menyediakan materi dan alat permainan yang mendukung sesuai dengan perkembangan anaknya, memberikan stimulus berbagai aspek perkembangan anak, serta memperhatikan pencapaian kemampuan anak.

Selain itu, meningkatkan regulasi diri anak dengan mengembangkan potensi anak melalui stimulus yang sesuai dengan tahapan perkembangannya merupakan salah satu alternatif jitu untuk meningkatkan perilaku toleran anak.

\section{DAFTAR PUSTAKA}

Abdullah, Anna Christina. 2009. Multicultural Education in Early Childhood: Issues and Challenges. CICE Hiroshima University, Journal of International Cooperation in Education, Vol.12 No.1 pp.159-175.

Al Munawar, Said Agil. 2003. Fiqih Hubungan Antar Agama. Jakarta: Ciputat Press.

Alismail, Halah Ahmed. (2016). Multicultural Education: Teachers' Perceptions and Preparation. Journal of Education and Practice ISSN 2222-1735 (Paper) ISSN 2222288X (Online) Vol.7, No.11, 2016. www.iiste.org

Arifin, Syamsul. (2010). Attitudes to Human Rights and Freedom of Religion or Belief in Indonesia. Yogyakarta: Penerbit Kanisius

Arriani, Farah. 2014. Jurnal Pendidikan Usia Dini Volume 8 Edisi 2, November 2014. Jakarta: Program Pascasarjana Universitas Negeri Jakarta.

As Saidi, Abd. Al Mu’tal. 1999. Kebebasan Berfikir dalam Islam. Yogyakarta: Adi Wacana.

Assyaukanie, Luthfi. Fatwa and Violence in Indonesia. Journal of Religion and Society. The Kripke Center. Volume 11 (2009).

Bodrova, E. Germeroth, \& Leong. 2013. Tools of Mind: The Vygotskyan Approach to Early Childhood Education. New York: Upper Side River.

Boisard, Marcel A. .tanpa tahun. Humanisme dalam Islam. Jakarta: Bulan Bintang

Brewer, Jo Ann. (2007). Introduction to Early Childhood Education. United States of America : Pearson Education, Inc.

Bronfenbrenner, Urie. 1979. The Ecology of Human Development: Experiments By Nature And Design. Cambridge:Harvard University Press. 
Faturochman. Pengantar Psikologi Sosial. Yogyakarta: Pustaka Pelajar, 2006.

Ghufron, M. Nur. 2010. Teori-Teori Psikologi. Jogjakarta: Ar Ruzz Media.

Hasyim, Umar . 1978. Toleransi dan Kemerdekaan Beragama dalam Islam Sebagai Dasar menuju Dialoq dan Kerukunan Antar Umat Beragama Surabaya: Bina Ilmu.

Hetherington, E.Mavis dkk. 2006. Child Psychology A Contemporary Viewpoint. (Sixth Edition). Newyork: The McGraw-Hill Companies, Inc.

Izzaty, Rita Eka. 2005. Mengenali Permasalahan Perkembangan Anak Usia TK. Jakarta: Departemen Pendidikan Nasional Direktorat Jenderal Pendidikan Tinggi Direktorat Pembinaan Pendidikan Tenaga Kependidikan dan Ketenagaan Perguruan Tinggi.

Jackman, Hilda L, 2012. Early Childhood Education Fifth Edition. USA: Wadsworth.

Jamaris, Martini. 2010. Orientasi Baru dalam Psikologi Pendidikan. Jakarta: Yayasan Penamas Murni.

Kemdikbud. 2017. Mengenalkan Keragaman Budaya pada Anak Usia Dini. anggunpaud.kemdikbud.go.id diakses tanggal 29 April 2017.

Kemenag. 2017. Halau Kelompok Radikal, Pimpinan PTKIN Deklarasikan Piagam Aceh. https://www.kemenag.go.id. Diakses 1 Mei 2017

Kreider, Holly. 2002. Getting Parents "Ready" for Kindergarten: The Role of Early Childhood Education. Family Involvement Network of Educators (FINE) Harvard Family Research Project www.finenetwork.org

Lestari, Sri. 2010. Modul Pendidikan Anak dalam Keluarga. Pontianak: Fakultas Keguruan dan Ilmu Pendidikan Universitas Tanjungpura.

Marsh, Tyson E.J. and Knaus, Christoper B. (2015). Fostering Movements or Silencing Voices: School Principals in Egypt and South Africa. The Role Of Educational Leadership In Promoting And/Or Challenging Racism As An Intentional Outcome Of Schooling. International Journal of Multicultural Education. Vol 17 No 1.

Menchik, Jeremy. Productive Intolerance: Godly Nationalism in Indonesia. Comparative Studies in Society and History 2014;56(3):591-621.

Mukuna, Truphena , Francis C. Indoshi. 2012. Parental Involvement and Perceptions of Their Role in Early Childhood Development Education Pedagogy in Kenya. International Journal of Current Research Vol. 4, Issue, 02, February, 2012, hh. 271272

Musa, Ali Masyur. 2014. Membumikan Islam Nusantara. Jakarta: Serambi.

Nokali, Nermeen E. El Heather J. Bachman, and Elizabeth Votruba-Drzal. 2010. Parent Involvement and Children's Academic and Social Development in Elementary School. Child Dev . 2010 ; 81(3): 988-1005. doi:10.1111/j.1467-8624.2010.01447.x. Child Dev. Author manuscript; available in pmc 2011 may 1. National Institue Of Health (NIH), h. 2

Papalia, Diane. 2012.Human Development. Jakarta: Kencana.

Patrikakou, Evanthia N. 2008. The Power of Parent Involvement: Evidence, Ideas, and Tools for Student Success. USA: Center on Innovation \& Improvement.

Ruslani. 2000. Masyarakat Dialog Antar Agama, Studi atas Pemikiran Muhammad Arkoun. Yogyakarta: Yayasan Bintang Budaya.

Santrock, John. W. 2009. Psikologi Pendidikan. Edisi Kedua. Jakarta: Kencana.

Seagal, Marilyn, et al. 2010. All About Child Care and Early Education. USA: Nova Southeastern University Family Center. 
Seefeldt, Carol et.al. 2010 Social Studies for the Preschool/Primary Child. New Jersey: Merrill Pearson.

Sheridan, S. M., Kim, E. M., Coutts, M. J., Sjuts, T. M., Holmes, S. R., Ransom, K. A., \& Garbacz, S. A. 2012. Clarifying parent involvement and family-school partnership intervention research: A preliminary synthesis (CYFS Working Paper No. 2012-4). Retrieved from the Nebraska Center for Research on Children, Youth, Families and Schools website: cyfs.unl.edu, h. 3

Tim Redaksi CCN Indonesia. Aturan di sekolah Hambat Sikap Toleransi pada Siswa. 25/5/2016. Diakses 2 Mei 2017.

Tim Redaksi Kompas. Survei Wahid Foundation: Indonesia Masih Rawan Intoleransi dan Radikalisme.

http://nasional.kompas.com/read/2016/08/01/13363111/survei.wahid.foundation.indo nesia.masih.rawan.intoleransi.dan.radikalisme?page=all Diakses 1 Mei 2017

Tonbuloğlu, B., Aslan, D., \& Aydin, H. (2016). Teachers' Awareness of Multicultural Education and Diversity in School Settings. Eurasian Journal of Educational Research, 64, 1-28.

Vaughn, Sharon dan Candace S Bos, Strategies for Teaching Students with Learning and Behavior Problem. Eight Edition. Boston: Pearson, 2012.

Weiss,Heather Margaret Caspe, M. Elena Lopez. 2006. Family Involvement in Early Childhood Education, Harvard Family Research Project, No. 1 in a series, spring 2006, Cambridge: Harvard Graduate School of Education.

Wirawan, Sarlito. 2009. Psikologi Sosial. Jakarta: Salemba Humanika.

Zirpoli , T.J. 2008. Behavior Management: Application For Teacher. New York: Pearson Allyn Bacon Prentice Hall. 